\title{
Pendampingan Kemandirian Ekonomi Kerakyatan melalui Program Pembuatan Pakan Alternatif Berbahan Baku Ampas Tahu dan Daun Talas pada Komunitas Budidaya Ikan Gurame di Metro Utara Kota Metro
}

\author{
Subandi, Nur Asiyah, Ida Fiteriani, Mispani \\ Universitas Islam Negeri (UIN) Raden Intan Lampung \\ subandi@radenintan.ac.id.,nuraisah@radenintan.ac.id, idafiteriani@radenintan.ac.id, \\ mispaniramli3@gmail.com
}

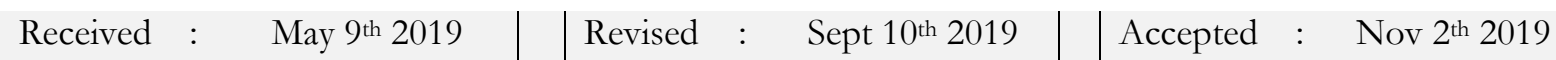

\begin{abstract}
Abstrak: Metro has a unit of business more than 99\% in the small and medium micro-industry sector, including the type of fresh fish water production. Metro city produces fish ponds of 2,122.01 tons per-year in two sub-districts, namely north metro and central metro. The monitoring community activity is aiming to utilize the organized community. The community owns assets to materialize the independence of the economy through cultication of fish carp manufacture of feed alternatives program made from raw pulp out and taro leaf. The monitoring use $A B C D$ (asset-based community development), so it can develop owned assets community aquaculture fish-arp to be self-sufficient in the economy and increase the social welfare. Results are strengthening of the aquaculture fish-carp capacity skills of the manufacture of alternatives feed and generate prosperity economics community.
\end{abstract}

Keyword: feed fish, tofu dregs, taro leaf, aquaculture fish carp

\section{Pendahuluan}

Kota Metro merupakan salah satu kota di Provinsi Lampung, Indonesia. Kota Metro dalam angka menunjukkan lebih dari 99\% dari unit bisnis yang ada terdiri sektor usaha mikro kecil. Berdasarkan data BPS 2016, Kota Metro menghasilkan produksi ikan air kolam (air tawar) sebanyak 2.122,01 ton/tahun. Usaha kecil tersebut merupakan penggerak perkembangan ekonomi terpenting bagi warga masyarakat lokal. ${ }^{1}$

Data statistik Kota Metro menunjukan pada tahun 2016 -sebagaimana data Metro dalam Angka- menunjukkan bahwa usaha kecil bagi para pedagang sayur, usaha grabatan, peternak rumah tangga, pedagang kaki lima dan usaha kuliner serta komunitas budidaya ikan air kolam meningkat

\footnotetext{
${ }^{1}$ Renny Oktafia, "Percepatan Pertumbuhan Usaha Mikro, Kecil Dan Menengah (UMKM) Melalui Perkuatan Lembaga Keuangan Mikro Syariah (Lkms) Di Jawa Timur," dalam Proceedings of Annual Conference for Muslim Scholars, 2017, 85-92.
} 
deras mencapai 28,7 \% dari seluruh Usaha Kecil dan Menengah. ${ }^{2}$ Dari fakta tersebut menunjukan bahwa usaha kecil merupakan kegiatan usaha yang mampu memperluas lapangan kerja dan memberikan pelayanan ekonomi secara luas kepada masyarakat dan sangat berperan dalam proses pemerataan dan peningkatan pendapatan masyarakat, mendorong pertumbuhan ekonomi serta salah satu perannya membantu mewujudkan stabilitas nasional .

Di Kota Metro Utara terdapat komunitas budidaya ikan gurame yang belum mendapat perhatian khusus dari pemerintah Kota Metro. Apalagi pada akhir-akhir tahun 2017 harga pakan meningkat tajam mencapai $15 \%$ per sak dengan isi $30 \mathrm{Kg}$ per sak harga semula Rp. 150.000 meningkat menjadi Rp. 180.000 secara ekonomi mengalami penurunan keuntungan (laba) apabila dibandingkan dengan harga pokok dengan harga jual turun $15 \%$ karena naiknya biaya produksi yang diakibatkan naiknya makanan ternak ikan dari semua ukuran (size). Dari data observasi di lapangan bahwa pada tahun 2017, sebanyak 25 orang budidaya ikan gurame dari komunitas tersebut, setiap kecamatan memiliki kelompok budidaya ikan gurame (budidaya ikan gurame), ${ }^{3}$ yang diketuai oleh ketua pengurus, dengan harapan ada proses keberlanjutan usaha tersebut (proses wirausaha ). Dari data jumlah 20 orang tersebut secara signifikan pada tahun 2018 dengan kurun waktu 1 tahun komunitas peliharaan ikan gurame air kolam meningkat $25 \%$ bertempat di empat kelurahan hingga bertambah 5 orang atau 1 kelompok dengan total 25 orang budidaya ikan gurame. Berdsarkan data dan fakta tersebut maka diperlukan pendampingan secara berkala untuk mampu dan terus mengembangkan semangat wirausaha bagi budidaya ikan air kolam (air tawar) sehingga mereka mampu hidup layak dan sejahtera. ${ }^{4}$

Jika ingin meningkatkan taraf hidup dan perekonomian masyarakat, maka harus berangkat dari diri masyarakat sendiri dan bukan sekedar pembangunan model top down yang telah banyak terbukti kurang efektif dalam membangun masyarakat. ${ }^{5}$ Karena pembangunan masyarakat yang ideal menekankan keterlibatan masyarakat secara sadar dalam pembangunan. Keterlibatan masyarakat ini menjadi sangat penting dan harus dilaksanakan jika masyarakat itu ingin berdaya. Dalam konsep pemberdayaan masyarakat, keterlibatan masyarakat menjadi prasyarat wajib yang harus dilaksanakan. Pemberdayaan merupakan alternatif baru dalam pengembangan masyarakat. Pemberdayaan menjadi lebih penting dalam pengembangan masyarakat karena menjadi berkaitan

\footnotetext{
2 Subandi Subandi dan Ahmad Fauzan, "Manajemen Good Corporate Governance pada Usaha Kecil dan Menengah Berbasis Sumber Daya Manusia," Akademika: Jurnal Pemikiran Islam 23, no. 1 (2018): 173-96.

${ }^{3}$ Ir Bambang Cahyono, Budi daya ikan air tawar: ikan gurami, ikan nila, ikan mas (Kanisius, 2000).

4 Yuli Rahmini Suci, "Perkembangan UMKM (Usaha mikro kecil dan menengah) di Indonesia," Cano Ekonomos 6, no. 1 (2017): 51-58.

${ }^{5}$ M. Miles, "Cbr Works Best the Way Local People See It and Build It," Asia Pacific disability rehabilitation journal 14, no. 1 (2003): 86-98.
} 
dengan pengembangan sumber daya manusia. Konsep utama dalam pemberdayaan adalah dengan dasar teori kekuasaan (power), yang berasal dari sosiologi struktur fungsional. Pemberdayaan sendiri merupakan sebuah rangkaian kegiatan untuk memperkuat dan mengoptimalkan keberdayaan kelompok lemah dalam masyarakat, termasuk individu-individu yang mengalami masalah kemiskinan. ${ }^{6}$

Masyarakat di Metro Utara Kota Metro ini termasuk masyarakat yang masih perlu adanya suatu pendampingan karena beberapa kondisi diantaranya: (1) Masyarakat tersebut homogen yaitu masyarakat pinggiran kota yang kurang mampu secara ekonomi; (2) Mulai tumbuh semangat untuk berwirausaha dengan kemandirian yang tinggi; (3) Memiliki pengalaman yang lama dalam budidaya ikan kolam (gurame dan lele dumbo); (4) Penjualan hasil panen ikan gurame dan lele sangat mudah pembeli datang sendiri; (5) Pertumbuhan wirausaha kecil di kota Metro mencapai $0.28 \%$ perlu didorong terus. dan beberapa kegiatan pendampingan yang telah dilakukan pada masyarakat disini diantara: (1) Pertumbuhan ikan gurame dengan makanan pengganti, ${ }^{7}$ (2) Pemanfaatan maggot sebagai pengganti tepung ikan untuk pakan buatan ikan gurame, ${ }^{8}$ (3) Pemberdayaan Masyarakat Desa Wakah, Kecamatan Ngrambe melalui pembuatan Pakan Lele Alternatif dari Ampas Tahu dan Probiotik oleh Yahya Ganda Yuliana dkk. ${ }^{9}$

Berdasarkan data kondisi keadaan masyarakat dan juga beberapa kegiatan pendampingan yang telah dilakukan sebelumnya, maka perlu adanya pendampingan lanjutan supaya ada peningkatan pendapatan ekonomi melalui pendampingan kemandirian ekonomi kerakyatan dengan program pembuatan pakan ikan alternatif berbahan baku ampas tahu dan daun talas. Sehingga melalui kegiatan pendampingan ini diharapkan ada perubahan kondisi ekonomi pada komunitas dampingan yaitu: Pertama, dapat menguatkan komunitas budidaya ikan gurame untuk mampu secara bersama-sama keluar dari ketidak berdayaan tentang mahalnya pakan ikan dengan membuat pakan alternatif berbahan baku ampas tahu dan daun talas. Kedua, komunitas secara bersama sama membangun pemahaman yang komperhensif budidaya ikan gurame. Ketiga, terbentuknya sikap wirausaha agar mampu mandiri dari pemeliharaan ikan gurame. Keempat,

\footnotetext{
6 Teguh Ansori, “Optimalisasi Peran Pemuda Melalui NTC (Ngrayun Tourism Creative) dalam Menciptakan Ekonomi Kreatif di Desa Selur Kecamatan Ngrayun Kabupaten Ponorogo," Engagement : Jurnal Pengabdian Kepada Masyarakat 2, no. 2 (2018): 176-90, https://doi.org/10.29062/engagement.v2i2.37.

7 Ning Praban Dani, Agung Budiharjo, dan Shanti Listyawati, "Komposisi pakan buatan untuk meningkatkan pertumbuhan dan kandungan protein ikan tawes (Puntius javanicus Blkr.)," Biosmart 7, no. 2 (2005): 83-90.

8 Agus Priyadi dkk., "Pemanfaatan Maggot Sebagai Pengganti Tepung Ikan Dalam Pakan Buatan Untuk Benih Ikan Balashark (Balanthiocheilus Melanopterus Bleeker)," Jurnal Riset Akuakultur 4, no. 3 (2016): 367-75.

9 A.A. Istri Andriyani, "Pemberdayaan Masyarakat Melalui Pengembangan Desa Wisata dan Implikasinya terhadap Ketahanan Sosial Budaya Wilayah (Studi di Desa Wisata Penglipuran Kecamatan Bangli Kabupaten Bangli Provinsi Bali)" (Universitas Gadjah Mada, 2016).
} 


\section{ENGAGEMENT}

Lurnal Pengabdian Kepada Masyarakat

ISSN : 2579-8375 (Print)

ISSN : 2579-8391 (Online)
This work is licensed under a Creative Commons

Attribution-ShareAlike 4.0 International License.

CC BY SA

terbangunnya kemandirian ekonomi untuk menuju kesejahteraan masyarakat.

\section{Metode}

Tujuan pendampingan komunitas budidaya ikan gurame ini diharapkan mampu mengembangkan dan memanfaatkan aset yang dimiliki oleh komunitas untuk menuju kemandirian ekonomi. Maka digunakan pendekatan Asset-Based Community Development $(A B C D)^{10}$. Melalui metode ini, komunitas mampu mengenali potensi/aset yang dimiliki, memanfaatkan aset berupa sumberdaya alam maupun manusia untuk meningkatkan kesejahteraan dan kemandirian ekonomi masyarakat.

Dengan pendekatan Asset-Based Community Development (ABCD), ${ }^{11}$ masyarakat sebagai subyek dampingan menjadi pelaku utama transformasi perubahan (social transformation) dengan menjadikan mobilisasi perkembangan Community-Driven Development (CDD). Melalui pendekatan ABCD akan menggali lebih jauh potensi-potensi yang ada dan mengembangkan sesuai dengan budaya serta kebiasaan yang telah dimiliki sebelumnya. ${ }^{12}$

Pelaksanakan program pendampingan ekonomi kerakyatan melalui program pembuatan pakan alternatif ini, maka langkah-langkah yang digunakan dalam kegiatan pendampingan yaitu melalui beberapa tahapan, antara lain: (1) Inkulturasi yaitu membudayakan bahan pakan alternatif yang ada di masyarakat, membangun komunitas sebagai media pertemuan; (2) To decovery, dengan menemukan rekayasa pakan yang telah ada dengan campuran daun talas dan ampas tahu; (3) To design, merencanakan tindakan pembuatan pakan alternatif dengan melakukan pelatihan-pelatihan; (4) To define, mengakomudasi kekuatan lokal yang telah telah untuk menghasilkan produk rekayasa dengan pakan alternatif yang mampu membantu komunitas dalam kemandirian ekonomi). ${ }^{13}$.

\section{Hasil dan Pembahasan}

\section{Strategi Pelatihan Pemahaman Dan Penguatan Komunitas.}

\section{a. Mengadakan Pelatihan Terprogram}

Goal : Menguatnya pemahaman komunitas

Purpose : Stakeholders dengan partisipasi tinggi

10 John Kretzmann dan John P. McKnight, “Assets-Based Community Development,” National Civic Review 85, no. 4 (1996): 23-29.

11 Wahyudin Darmalaksana, "Manual Penulisan Proposal Pengabdian Berbasis Riset," t.t.

12 Bilqis Amaliah, Chastine Fatichah, dan M. Rahmat Widyanto, "ABCD feature extraction of image dermatoscopic based on morphology analysis for melanoma skin cancer diagnosis," Jurnal Ilmu Komputer dan Informasi 3, no. 2 (2012): 82-90.

${ }^{13}$ Nadhir Salahuddin, "Panduan KKN ABCD UIN Sunan Ampel Surabaya Asset Based Community-Driven Development $(A B C D)$ " (LP2M UIN Sunan Ampel Surabaya, 2015). 
ENGAGEMENT

Lurnal Pengabdian Kepada Masyarakat

ISSN : 2579-8375 (Print)

ISSN : 2579-8391 (Online)
This work is licensed under a Creative Commons

Attribution-ShareAlike 4.0 International License.

CC BY SA

Output-1 : Penguatan kemandirian ekonomi

\begin{tabular}{|c|c|c|c|c|c|c|}
\hline No & $\begin{array}{l}\text { Kegiatan dan } \\
\text { Sub Kegiatan }\end{array}$ & Target & Indikator & Kegiatan & Personel & $\begin{array}{c}\text { Alat } \\
\text { verifikasi }\end{array}$ \\
\hline $\bar{A}$ & $\begin{array}{l}\text { Membangun } \\
\text { dan } \\
\text { mendesain } \\
\text { forum-forum } \\
\text { yang dapat } \\
\text { mendorong } \\
\text { terwujudnya } \\
\text { komunikasi } \\
\text { yang efektif } \\
\text { pembedayaan } \\
\text { budidaya ikan } \\
\text { kolam gurame } \\
\text { dan lele }\end{array}$ & $\begin{array}{l}\text { Menghasilkan } \\
\text { komunikasi } \\
\text { yang efektif } \\
\text { pemberdayaan } \\
\text { budidaya ikan } \\
\text { air kolam } \\
\text { dengan } \\
\text { pembuatan } \\
\text { pakan } \\
\text { alternatif }\end{array}$ & $\begin{array}{l}\text { Adanya } \\
\text { kegiatan dan } \\
\text { komunikasi } \\
\text { yang } \\
\text { melibatkan } \\
\text { pihak-pihak } \\
\text { terkait tentang } \\
\text { pembuatan } \\
\text { pakan alternatif } \\
\text { penganti pakan } \\
\text { ikan kemasan }\end{array}$ & Juli 2019 & $\begin{array}{l}\text { Fasilitator, } \\
\text { peneliti, } \\
\text { CO, } \\
\text { perekam } \\
\text { proses }\end{array}$ & $\begin{array}{l}\text { Fieldnote, } \\
\text { laporan } \\
\text { hasil, } \\
\text { dokumentasi } \\
\text { foto dan } \\
\text { video }\end{array}$ \\
\hline A.1. & $\begin{array}{l}\text { Diskusi dengan } \\
\text { tokoh } \\
\text { masyarakat } \\
\text { tentang } \\
\text { penguatan } \\
\text { budidaya ikan } \\
\text { gurame dan } \\
\text { lele dengan } \\
\text { pakan buatan }\end{array}$ & $\begin{array}{l}\text { Membangun } \\
\text { kesadaran } \\
\text { pada tingkat } \\
\text { informan } \\
\text { tentang } \\
\text { pentingya } \\
\text { pembuatan } \\
\text { pakan } \\
\text { alternatif }\end{array}$ & $\begin{array}{l}\text { Terbangunnya } \\
\text { pemahaman } \\
\text { tentang } \\
\text { pembuatan } \\
\text { pakan ikan } \\
\text { alternatif }\end{array}$ & $\begin{array}{l}\text { Agustus } \\
2019\end{array}$ & $\begin{array}{l}\text { Fasilitator, } \\
\text { peneliti, } \\
\text { CO, FGD, } \\
\text { perekam } \\
\text { proses }\end{array}$ & $\begin{array}{l}\text { Fieldnote, } \\
\text { laporan } \\
\text { hasil, } \\
\text { dokumentasi } \\
\text { foto dan } \\
\text { video }\end{array}$ \\
\hline A.2. & $\begin{array}{l}\text { Diskusi dengan } \\
\text { elemen } \\
\text { masyarakat } \\
\text { Islam ,tentang } \\
\text { Pemeliharaan } \\
\text { ikan kolam } \\
\text { dengan pakan } \\
\text { buatan }\end{array}$ & $\begin{array}{l}\text { Membangun } \\
\text { kesadaran } \\
\text { tentang maat } \\
\text { pembuatan } \\
\text { pakan ikan } \\
\text { alternatif }\end{array}$ & $\begin{array}{l}\text { Adanya } \\
\text { kegiatan dan } \\
\text { komunikasi } \\
\text { pembuatan } \\
\text { pakan } \\
\text { alternatif. }\end{array}$ & $\begin{array}{l}\text { Agustus } \\
2019\end{array}$ & $\begin{array}{l}\text { Fasilitator, } \\
\text { peneliti, } \\
\mathrm{CO}, \\
\text { perekam } \\
\text { proses }\end{array}$ & $\begin{array}{l}\text { Fieldnote, } \\
\text { laporan } \\
\text { hasil, } \\
\text { dokumentasi } \\
\text { foto dan } \\
\text { video }\end{array}$ \\
\hline A.3. & $\begin{array}{l}\text { Diskusi dengan } \\
\text { semua elemen } \\
\text { Stake holders } \\
\text { fokus tugas } \\
\text { dan fungsi } \\
\text { tetang } \\
\text { pemanfaatan } \\
\text { pekarangan } \\
\text { dan } \\
\text { pemeliharaan } \\
\text { ikan air kolam }\end{array}$ & $\begin{array}{l}\text { Membangun } \\
\text { kesadaran } \\
\text { tentang } \\
\text { Pemeliharaan } \\
\text { ikan air kolam }\end{array}$ & $\begin{array}{l}\text { Adanya } \\
\text { kegiatan dan } \\
\text { komunikasi } \\
\text { dalam lingkup } \\
\text { yang lebih luas } \\
\text { tentang } \\
\text { pentingnya } \\
\text { usaha tambahn } \\
\text { dengan } \\
\text { memanfaatkan }\end{array}$ & $\begin{array}{l}\text { Agustus } \\
2019\end{array}$ & $\begin{array}{l}\text { Fasilitator, } \\
\text { peneliti, } \\
\text { CO, } \\
\text { perekam } \\
\text { proses }\end{array}$ & $\begin{array}{l}\text { Fieldnote, } \\
\text { laporan } \\
\text { hasil, } \\
\text { dokumentasi } \\
\text { foto dan } \\
\text { video }\end{array}$ \\
\hline
\end{tabular}


ENGAGEMENT

Lurnal Pengabdian Kepada Masyarakat

ISSN : 2579-8375 (Print)

ISSN : 2579-8391 (Online)
This work is licensed under a Creative Commons

Attribution-ShareAlike 4.0 International License.

\begin{tabular}{|l|l|l|l|l|l|l|}
\hline $\begin{array}{l}\text { dengan pakan } \\
\text { buatan }\end{array}$ & $\begin{array}{l}\text { halaman } \\
\text { /lahan kosong }\end{array}$ & & & & \\
\hline A.4. & $\begin{array}{l}\text { Academic } \\
\text { Review }\end{array}$ & $\begin{array}{l}\text { Menghasilkan } \\
\text { rumusan } \\
\text { tentang } \\
\text { pembuatan } \\
\text { pakan ikan } \\
\text { alternatif }\end{array}$ & $\begin{array}{l}\text { Adanya konsep } \\
\text { strategis } \\
\text { Pemeliharaan } \\
\text { ikan kolam. } \\
\text { Dengan } \\
\text { makanan } \\
\text { alternatif. }\end{array}$ & $\begin{array}{l}\text { Agustus } \\
2019\end{array}$ & $\begin{array}{l}\text { Fasilitator, } \\
\text { peneliti, } \\
\text { CO, } \\
\text { perekam } \\
\text { proses }\end{array}$ & $\begin{array}{l}\text { Fieldnote, } \\
\text { laporan } \\
\text { hasil, } \\
\text { dokumentasi } \\
\text { foto dan } \\
\text { video }\end{array}$ \\
\hline
\end{tabular}

Dari perencanaan yang matang dan dimulai dari pelatihan yang terprogram, kemudian dilakukan praktek yang dibimbing oleh narasumber yang kompeten, serta pelaksanaan FGD, ${ }^{14}$ yang terprogram antara komunitas, narasumber dan pihak LP2M UIN Raden Intan Lampung, maka dihasilkan tiga kegiatan yang mampu menghasilkan kompetensi dan beberapa penguatan komunitas dari hasil proses pendampingan.

\section{Penguatan Pendampingan}

a. Komunitas memiliki pengetahuan tentang teknologi tepat guna ${ }^{15}$ dan pemahaman tentang perhitungan secara ekonomi penetapan harga pokok ikan gurame, yaitu perbandingan antara harga pokok produksi dengan harga jual per $1 \mathrm{Kg}$ gurame .

b. Komunitas memiliki pemahaman tentang pakan alterenatif terdiri dari ampas tahu ${ }^{16}$. Ampas tahu terdapat kandungan gizi, yaitu protein $(23,55)$, lemak $(5,54)$, karbohidrat $(26,92)$, abu $(17,03)$, serat kasar $(16,5)$, dan air $(10,4) .{ }^{17}$ Sampah ikan asin mengandung energi 193 kilokalori protein, 42 gram , lemak 1,5 gram kalsium 200 mmg, vitamin A dan vitamin B1 dan 3). bakatul

\footnotetext{
14 Astridya Paramita dan Lusi Kristiana, “Teknik Focus Group Discussion Dalam Penelitian Kualitatif,” Buletin Penelitian Sistem Kesehatan 16, no. 2 Apr (2013).

15 Corinthias Pamatang Morgana Sianipar dkk., "Community Empowerment Through Appropriate Technology: Sustaining the Sustainable Development," Procedia Environmental Sciences 17 (2013): 1007-1016.

16 Maita Atmi Nastiti, "Pengaruh konsentrasi natrium metabisulfit (Na2S2O5) dan suhu pengeringan terhadap karakteristik tepung ampas tahu," Jurnal Bioproses Komoditas Tropis 2, no. 2 (2014): 100-106.

17 Dwi Linna Suswardany dan Yuli Kusumawati, "Peran Efective Microorganism-4 (EM-4) dalam meningkatkan kualitas kimia kompos ampas tahu," 2006.
} 


\section{ENGAGEMENT}

Lurnal Pengabdian Kepada Masyarakat

ISSN : 2579-8375 (Print)

ISSN : 2579-8391 (Online)
This work is licensed under a Creative Commons

Attribution-ShareAlike 4.0 International License.

CC BY SA

serat, karbohidrat, lemak dan vitamin mineral ${ }^{18}$. Kandungan yang ada pada ikan asin kering 193 kilokalori, kandungan protein 42 gram, kandungan lemak 1,5 gram, kandungan kalsium 200 miligram, kandungan fosfor 300 miligram, dan kandungan zat besi 3 miligram. Sedangan kandungan ikan asin kering juga terdapat vitamin A sebanyak 0 IU, vitamin B1 0,01 miligram dan vitamin C 0 dalam miligram per 100 gram.

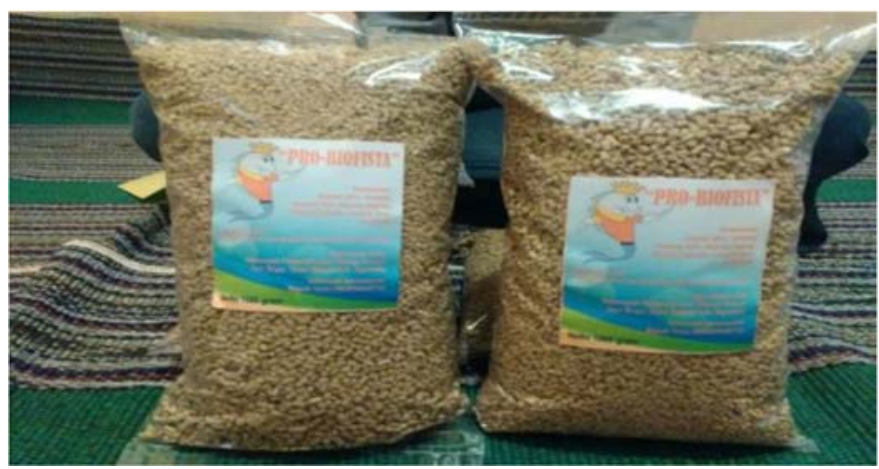

Gambar 1. Pakan ternak ikan gurame (ampas tahu, ikan asin, daun talas) sebagai Produk Rekayasa.

\section{Peningkatan Pengetahuan dan Ketrampilan (Skill)}

Subyek dampingan dalam program pemberdayaan masyarakat tidak selalu pada posisi "gelas kosong". Artinya mereka bukanlah individu atau kelompok yang sama sekali tidak memiliki pengetahuan dan skill sama sekali. ${ }^{19}$ Ada beberapa keterampilan yang didapatkan, antara lain sebagai berikut: (1) adanya peningkatan kapasitas diri; (2) adanya keterampilan subyek pemberdayaan dengan pembuatan pakan alternatif ampas tahu, ikan asin dan daun talas diramu menjadi bentuk butiran pakan ikan. Tujuan pemberdayaan dalam bidang ekonomi tidak sematamata hanya sekedar peningkatan pendapatan ekonomi, akan tetapi peningkatan pengetahuan dan keterampilan (skill) adalah merupakan aset berharga yang dimiliki masyarakat. Dalam upaya menjadikan subyek dampingan menjadi individu atau kelompok yang well-educated sesuai dengan kapasitas kelompok. Hal ini dilakukan untuk mendorong komunitas subyek dampingan dapat menyesuaikan diri dengan kehidupan dan masalah ekonomi yang dihadapi di lain waktu atau di lain tempat. ${ }^{20}$

\footnotetext{
18 Hafni Rahmawati, "Karakterisasi gelatin hasil ekstraksi kulit segar dan kering dari beberapa jenis ikan air laut dan tawar" (Universitas Gadjah Mada, 2008).

${ }^{19}$ Hamidah Maryunianta dan M Jufri, "Evaluasi Kinerja USAha Agribisnis Kerapu (Kasus: Desa Pulau Sembilan, Kecamatan Pangkalan Susu, kabupaten Langkat).," Journal of Agriculture and Agribusiness Socioeconomics 3, no. 4 (2014).

20 Cahyono, Budi daya ikan air tawar: ikan gurami, ikan nila, ikan mas.
} 


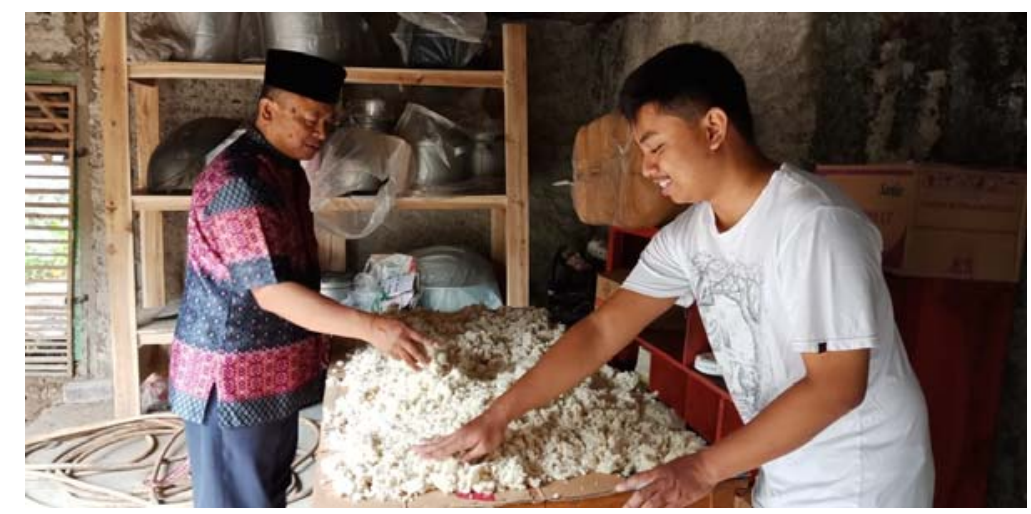

Gambar 2. Proses Pembuatan Pakan dari Ampas Tahu

Program pemberdayaan umumnya tidak jauh dari kegiatan ekonomi yang target dan tujuannya adalah adanya peningkatan kualitas hidup subyek pemberdayaan. ${ }^{21}$ Pemberdayaan ekonomi melalui pemeliharaan ikan air tawar mampu memberikan peningkatan pengetahuan dan peningkatan ekonomi. Program pemberdayaan kepada masyarakat mampu membawa perubahan bagi kehidupan subyek pemberdayaan. ${ }^{22}$ Pendampingan pada komunitas ikan lele dan gurame peningkatan peran produktivitas kerja mewujudkan meningkatkan kesejahteraan. ${ }^{23}$ Pengetahuan sangat dibutuhkan untuk menumbuhkan jiwa wirausaha pada masyarakat budidaya ikan gurame agar mampu menumbuh kembangkan dan menyampaikan kepada yang lain pentingnya pemanfaatan pekarangan untuk memelihara ikan kolam air tawar, dan dengan keterampilan mencari alternatif pakan ikan yang mengandung banyak gizi, protein dan karbohidrat tetapi harganya murah hal tersebut diperlukan ketrampilan rekayasa pembuatan pakan alternatif, bila dibandingkan dengan pakan asli pelet, mengapa ini dilakukan karena sumber bahan telah ada di masyarakat dan mudah untuk didapat harganya relatif murah sehingga akan mampu menekan biaya operasional dan meningkatkan keuntungan.

\section{Kemandirian Masyarakat}

Kemandirian ekonomi subyek dampingan merupakan tujuan akhir dan sekaligus menjadi target utama yang harus dicapai pemberdayaan komunitas. ${ }^{24}$ Untuk menghindarkan mereka dari

\footnotetext{
${ }^{21}$ Patricia A. Wilson, "Empowerment: Community Economic Development from the Inside Out," Urban Studies 33, no. 4-5 (1996): 617-630.

22 Adi Fahrudin, "Pemberdayaan, Partisipasi dan Penguatan Kapasitas Masyarakat," Bandung: Humaniora, 2011.

23 Aris Munandar, "Peran negara dalam penguatan program pemberdayaan masyarakat," Jurnal Poelitik 4, no. 1 (2008): 151-62.

${ }^{24}$ Lambang Trijono, "Strategi pemberdayaan komunitas lokal: menuju kemandirian daerah,” Jurnal Imu Sosial dan Ilmu Politik 5, no. 2 (2001): 215-35.
} 


\section{ENGAGEMENT}

Lurnal Pengabdian Kepada Masyarakat

ISSN : 2579-8375 (Print)

ISSN : 2579-8391 (Online)
This work is licensed under a Creative Commons

Attribution-ShareAlike 4.0 International License.

CC BY SA

ketergantungan terhadap pelaksanaan program, lingkungan dan ketergantungan terhadap pemberi bantuan, terutama dari pemerintah maupun non pemerintah. Dengan adanya kemandirian ekonomi, maka subyek dampingan siap untuk "dilepas" oleh pelaksana program dan diharapkan mereka mampu melanjutkan program atau membuat kreasi dan inovasi program baru sesuai dengan kemampuan dan kebutuhan yang mereka dapatkan selama program pemberdayaan. Kemandirian akan dimiliki oleh komunitas dengan menetapkan sasaran dampingan yang untuk mampu membentuk kantong-kantong (klaster) kemandirian ekonomi, dengan menselaraskan kekuatan lokal yang telah dimiliki dan dibantu oleh lembaga-lembaga yang bermitra, melalui FGD komunitas dan lembaga mitra menghasilkan rumusan, yaitu perencanaan pelatihan sampai dengan praktek pembuatan pakan alternatif, dengan pakan alternatif yang dibuat oleh komunitas, mampu membangkitkan keterampilan, dengan keterampilan yang diperoleh sebagai modal awal untuk memupuk kemandirian masyarakat dampingan.

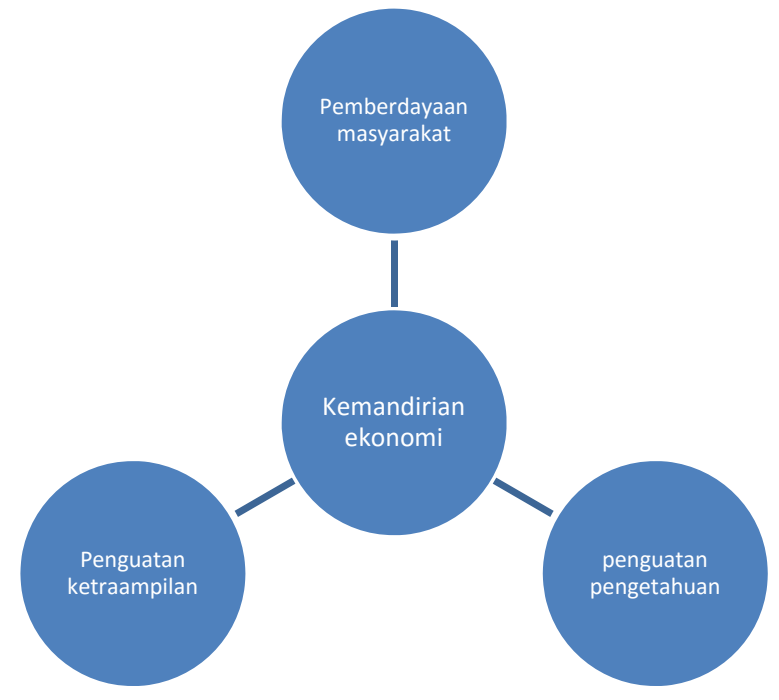

Gambar 3. Bagan kompetensi subyek dampingan

Pelaksanaan program pendampingan komunitas pemeliharaan ikan gurame dengan makanan alternatif maka pihak-pihak yang terlibat (stakeholders) dan bentuk keterlibatannya adalah sebagai berikut: Pertama, Dinas pertanian, perikanan dan katahanan pangan Kota Metro. Keterlibatan adalah menindaklanjuti hasil penelitian dan pendampingan yang dilakukan oleh pengusul, selanjutnya dijadikan kebijakan pemerintah daerah untuk meningkatkan wirausaha dan mengurangi kemiskinan menuju kesejahteraan subyek dampingan. Kedua, MWC NU Kecamatan Metro Barat. Bentuk keterlibatan sebagai lembaga kemasyarakat Islam NU yang ada di setiap kecamatan yang mamapu mendorong kegiatan keagamaan yang berbasis komonitas budaya lokal. Dengan adanya kerjasama antara pihak MWC NU dengan LP2M yang difasilitas oleh pihak 


\section{ENGAGEMENT}

Lurnal Pengabdian Kepada Masyarakat

ISSN : 2579-8375 (Print)

ISSN : 2579-8391 (Online)
This work is licensed under a Creative Commons

Attribution-ShareAlike 4.0 International License.

CC BY SA

kampus, maka sangat mendukung terhadap program pengentasan kemiskinan melalui kegiatan pedampingan. Keempat, BMT Atha Buana. Kelima, Muslimat Kota Metro sebagai penggerak bagi ibu-ibu untuk membantu pengolahan bahan pakan yang dilakukan suaminya (gender). Lembaga Zakat, Infaq dan Shodakah produktif mampu mendorong pendanaan pemberdayaan masyarakat. ${ }^{25}$ Kemandirian masyarakat dapat dilakukan melalui usaha-usaha mikro yang menjadi menopang ekonomi sekaligus membangun kekuatan lokal yang telah dimiliki sejak lama dimasyarakat .

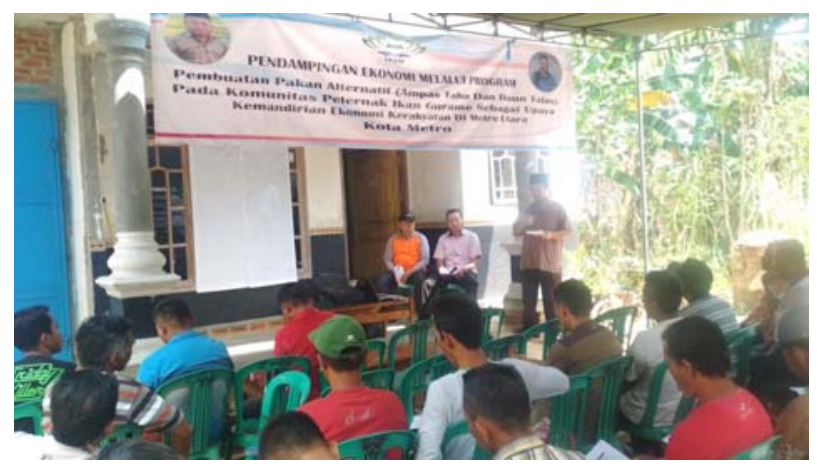

Gambar 4. Sosialisasi Pelaksanaan Program Pendampingan

\section{Simpulan}

Pendampingan komunitas budidaya ikan gurame sebagai upaya meningkatkan kemandirian ekonomi masyarakat melalui pembuatan pakan alternatif berbahan baku ampas tahu dan daun talas ini melibatkan stakeholders antara lain Dinas Pertanian dan Tanaman Pangan Kota Metro, pihak penyandang dana dari BMT dan Lazis NU, organisasi Muslimat NU dan LP2M UIN Raden Intan, serta kelompok pengajian yang ada di masyarakat. Sebagai upaya penguatan kapasitas komunitas berupa pemahaman tentang wirausaha dan teknologi tepat guna yaitu pembuatan pakan alternatif sebagai pengganti pakan ikan gurame, dari aksi pendampingan ini mampu mengembangkan antara lain: (1) menguatkan pengetahuan pengelolaan ikan air tawar secara bersama-sama; (2) menguatkan keterampilan pembuatan pakan alternatif pada komunitas pememlihara ikan gurame; (3) terbentuknya kantong-kantong komunitas budidaya ikan gurame; dan (4) menguatnya sikap kemandirian ekonomi melalui proses wirausaha. Menguatnya usaha mikro melalui budidaya ikan gurame, dampaknya masyarakat mampu menyiapkan pakan ikan sebagai asupan gizi utama dalam bidang budidaya ikan gurame secara mandiri dengan harga relatif murah dan tersedia di alam setiap saat diperlukan.

25 Subandi Subandi, "Manajemen Zakat, Infaq Dan Shadakah (Zis) Produktif (Zis Berbasis Kewirausahaan dI LAZIZNU Kota Metro Tahun 2015)," Fikri: Jurnal Kajian Agama, Sosial dan Budaya 1, no. 1 (2016): $143-68$.

Volume 3, Number 2, November 2019|170 Pendampingan Kemandirian Ekonomi Kerakyatan melalui Program Pembuatan Pakan Alternatif Berbahan Baku Ampas Tahu dan Daun Talas pada Komunitas Budidaya Ikan Gurame di Metro Utara Kota Metro 


\section{ENGAGEMENT}

Lurnal Pengabdian Kepada Masyarakat

ISSN : 2579-8375 (Print)

ISSN : 2579-8391 (Online)
This work is licensed under a Creative Commons

Attribution-ShareAlike 4.0 International License.

CC BY SA

\section{Daftar Pustaka}

Amaliah, Bilqis, Chastine Fatichah, dan M. Rahmat Widyanto. "ABCD feature extraction of image dermatoscopic based on morphology analysis for melanoma skin cancer diagnosis." Jurnal Ilmu Komputer dan Informasi 3, no. 2 (2012): 82-90.

Andriyani, A A Istri. "Pemberdayaan Masyarakat Melalui Pengembangan Desa Wisata dan Implikasinya Terhadap Ketahanan Sosial Budaya Wilayah (Studi di Desa Wisata Penglipuran Kecamatan Bangli Kabupaten Bangli Provinsi Bali).” Universitas Gadjah Mada, 2016.

Cahyono, Ir Bambang. Budi daya ikan air tawar: ikan gurami, ikan nila, ikan mas. Kanisius, 2000.

Dani, Ning Praban, Agung Budiharjo, dan Shanti Listyawati. "Komposisi pakan buatan untuk meningkatkan pertumbuhan dan kandungan protein ikan tawes (Puntius javanicus Blkr.)." Biosmart 7, no. 2 (2005): 83-90.

Darmalaksana, Wahyudin. "Manual Penulisan Proposal Pengabdian Berbasis Riset," t.t.

Fahrudin, Adi. "Pemberdayaan, Partisipasi dan Penguatan Kapasitas Masyarakat." Bandung: Humaniora, 2011.

Kretzmann, John, dan John P. McKnight. “Assets-Based Community Development.” National Civic Review 85, no. 4 (1996): 23-29.

Maryunianta, Hamidah, dan M Jufri. "Evaluasi Kinerja Usaha Agribisnis Kerapu (Kasus: Desa Pulau Sembilan, Kecamatan Pangkalan Susu, kabupaten Langkat)." Journal of Agriculture and Agribusiness Socioeconomics 3, no. 4 (2014).

Miles, M. "CBR Works Best the Way Local People See It and Build It." Asia Pacific disability rehabilitation journal 14, no. 1 (2003): 86-98.

Munandar, Aris. "Peran negara dalam penguatan program pemberdayaan masyarakat." Jurnal Poelitik 4, no. 1 (2008): 151-62.

Nastiti, Maita Atmi. "Pengaruh konsentrasi natrium metabisulfit (Na2S2O5) dan suhu pengeringan terhadap karakteristik tepung ampas tahu." Jurnal Bioproses Komoditas Tropis 2, no. 2 (2014): 100-106.

Oktafia, Renny. "Percepatan Pertumbuhan Usaha Mikro, Kecil dan Menengah (UMKM) Melalui Perkuatan Lembaga Keuangan Mikro Syariah (LKMS) di Jawa Timur." Dalam Proceedings of Annual Conference for Muslim Scholars, 85-92, 2017.

Paramita, Astridya, dan Lusi Kristiana. "Teknik Focus Group Discussion Dalam Penelitian Kualitatif." Buletin Penelitian Sistem Kesehatan 16, no. 2 Apr (2013).

Priyadi, Agus, Zafril Imran Azwar, I Wayan Subamia, dan Saurin Hem. "Pemanfaatan Maggot Sebagai Pengganti Tepung Ikan Dalam Pakan Buatan Untuk Benih Ikan Balashark (Balanthiocheilus Melanopterus Bleeker).” Jurnal Riset Akuakultur 4, no. 3 (2016): 367-75. 


\section{ENGAGEMENT}

Lurnal Pengabdian Kepada Masyarakat

ISSN : 2579-8375 (Print)

ISSN : 2579-8391 (Online)
This work is licensed under a Creative Commons

Attribution-ShareAlike 4.0 International License. CC BY SA

Rahmawati, Hafni. "Karakterisasi gelatin hasil ekstraksi kulit segar dan kering dari beberapa jenis ikan air laut dan tawar." Universitas Gadjah Mada, 2008.

Salahuddin, Nadhir, dkk. "Panduan KKN ABCD UIN Sunan Ampel Surabaya Asset Based Community-Driven Development (ABCD).” LP2M UIN Sunan Ampel Surabaya, 2015.

Sianipar, Corinthias Pamatang Morgana, Gatot Yudoko, Akbar Adhiutama, dan Kiyoshi Dowaki. "Community Empowerment Through Appropriate Technology: Sustaining the Sustainable Development.” Procedia Environmental Sciences 17 (2013): 1007-1016.

Subandi, Subandi. "Manajemen Zakat, Infaq dan Shadakah (ZIS) Produktif (ZIS Berbasis Kewirausahaan di LAZIZNU Kota Metro Tahun 2015)." Fikri: Jurnal Kajian Agama, Sosial dan Budaya 1, no. 1 (2016): 143-68.

Subandi, Subandi, dan Ahmad Fauzan. "Manajemen Good Corporate Governance Pada Usaha Kecil dan Menengah Berbasis Sumber Daya Manusia." AKADEMIKA: Jurnal Pemikiran Islam 23, no. 1 (2018): 173-96.

Suci, Yuli Rahmini. "Perkembangan UMKM (Usaha mikro kecil dan menengah) di Indonesia." Cano Ekonomos 6, no. 1 (2017): 51-58.

Suswardany, Dwi Linna, dan Yuli Kusumawati. "Peran Efective Microorganism-4 (EM-4) dalam meningkatkan kualitas kimia kompos ampas tahu," 2006.

Teguh Ansori. "Optimalisasi Peran Pemuda Melalui NTC (Ngrayun Tourism Creative) dalam Menciptakan Ekonomi Kreatif di Desa Selur Kecamatan Ngrayun Kabupaten Ponorogo." Engagement : Jurnal Pengabdian Kepada Masyarakat 2, no. 2 (2018): 176-90. https://doi.org/10.29062/engagement.v2i2.37.

Trijono, Lambang. "Strategi pemberdayaan komunitas lokal: menuju kemandirian daerah." Jurnal Ilmu Sosial dan Ilmu Politik. 5, no. 2 (2001): 215-35.

Wilson, Patricia A. "Empowerment: Community Economic Development from the Inside Out." Urban Studies 33, no. 4-5 (1996): 617-630. 